\title{
Konsep Informatika Dan Computational Thinking Di Dalam Kurikulum Sekolah Dasar, Menengah, Dan Atas
}

\author{
Ayu Pertiwi ${ }^{1}$, Abdul Syukur ${ }^{2}$, Titien Suhartini ${ }^{3}$, Affandy $^{4}$ \\ 1,2,3,4 Fakultas Ilmu Komputer Universitas Dian Nuswantoro \\ E-mail: ${ }^{1}$ ayu.pertiwi@dsn.dinus.ac.id, ${ }^{2}$ abah.syukur01@dsn.dinus.ac.id, \\ ${ }^{3}$ titien.suhartini@dsn.dinus.ac.id, ${ }^{4}$ affandy@dsn.dinus.ac.id
}

\begin{abstract}
Abstrak
Informatika atau komputer sains adalah mata pelajaran yang penting bagi pendidikan sekolah saat ini. Informatika dapat disajikan sebagai disiplin ilmu untuk memahami teknologi dengan cara yang lebih mendalam dibalik program komputer. Dengan dibawanya Informatika ke sekolah adalah mempersiapkan kaum muda untuk menjadi kreator teknologi informasi bukan hanya sekedar pengguna teknologi informasi. Untuk mencapai hal tersebut, perlu dikenalkannya konsep informatika mulai dari pendidikan dasar, sekolah menengah, dan juga sekolah menengah atas. Di lain pihak, kita perlu membantu orang untuk memecahkan masalah dengan menggunakan teknologi dan mengembangkan pemikiran komputasi di berbagai bidang. Makalah ini menyajikan tentang peran Indonesia secara khusus Fakultas Ilmu Komputer Universitas Dian Nuswantoro yang ada di kota Semarang dalam memperkenalkan pemikiran komputasi melalui Bebras Computational Thinking.
\end{abstract}

Kata kunci: ilmu komputer, Bebras, pemikiran komputasi

\begin{abstract}
Informatics or Computer Science is an important subject for school education today. Informatics can be presented as a scientific discipline to understand technology in a way that is more deeply behind computer programs. With the introduction of informatics to schools is to prepare young people to become creators of information technology not just users of information technology. To achieve this, informatics concepts need to be introduced from basic education, high school, and high school. On the other hand, we need to help people solve problems by using technology and developing computational thinking in various fields. This paper presents the role of Indonesia specifically through Faculty of Computer Science Dian Nuswantoro University in introducing computational thinking through Bebras Computational Thinking
\end{abstract}

Keywords: computer science, Bebras, Computational Thinking

\section{PENDAHULUAN}

Pada saat ini, komputer sudah merasuki hampir di semua bidang, sehingga Computational Thinking (CT) sudah menjadi kemampuan yang wajib untuk dikuasai oleh manusia di abad ke21 ini. Sejak tahun 2014, beberapa negara menghapus mata pelajaran TIK di sekolah, dan menggantikannya dengan pelajaran informatika yang lebih bersifat keilmuan. Google, code.org, dan ACM juga ikut mendukung lahirnya K12 Curriculum Framework, yang saat ini notabene telah diimplementasikan menjadi standar kurikulum untuk sekolah dasar dan menengah negara maju. Standar kurikulum K12 yang dirintis oleh ACM dan CSTA menjadi salah satu aspek yang menjadi target kompetensi dalam kurikulum tersebut. Indonesia sudah mengadaptasi K12 CS 
Curriculum tersebut untuk diimplementasikan sebagai kurikulum nasional pendidikan dasar dan menengah, yang sudah disahkan pada tanggal 20 Desember 2018 sebagai Peraturan Menteri Pendidikan dan Kebudayaan no 37 tahun 2018 sebagai perubahan dari Permendikbud nomor 24 tahun 2016. Guru-guru yang pada awalnya hanya mengajarkan TIK dengan fokus penggunaan tools, perlu ditransformasi menjadi guru yang mampu mengajar aspek keilmuan informatika, termasuk CT. Pada tahun 2016, Indonesia diundang menjadi observer pada acara workshop tahunan Bebras Internasional, dan sejak tahun tahun 2017 Indonesia secara resmi diterima menjadi anggota komunitas Bebras Internasional. Para Pembina TOKI (Tim Olimpiade Komputer Indonesia) ditunjuk menjadi NBO (National Board Organization) berkewajiban untuk menyelenggarakan tantangan ("challenge") setiap tahun. Sebelum menyelenggarakan tantangan diperlukan program-program pengenalan CT ke sekolah-sekolah. Untuk dapat menjangkau seluruh wilayah Indonesia yang sangat luas, NBO Indonesia melibatkan mitra (universitas) untuk membina sekolah-sekolah. Saat ini, NBO telah bekerja sama dengan lebih dari 50 Bebras Biro, yaitu Program studi informatika (computing) dari berbagai perguruan tinggi di Indonesia, baik perguruan tinggi negeri maupun swasta. Pada mulanya pembina TOKI hanya menyiapkan siswa SMA (Sekolah Menengah Atas) untuk IOI (International Olymiade in Informatics) melalui dua tahun seleksi berjenjang dan 4 pelatnas, tetapi sejak tahun 2016 juga membina tingkat SD (Sekolah Dasar) dan SMP (Sekolah Menengah Pertama) dalam Tantangan Bebras [1]. Kerjasama untuk mempersiapkan siswa menghadapi lomba, memberikan pelatihan kepada guru, dan menyelenggarakan lomba, telah menjadikan komunitas Bebras Indonesia sebagai sebuah komunitas yang bertekad untuk menyebarkan CT ke generasi muda. Program pengenalan CT ke berbagai sekolah telah membuka mata kalangan pendidikan (pemerintah, sekolah, guru, dan siswa) bahwa kemampuan problem solving, berpikir kritis dan kreatif, ternyata dapat diajarkan dan disukai oleh anak-anak. Di beberapa negara, sejak tahun 2014 telah menghapus mata pelajaran TIK dari sekolah, dan menggantikannya dengan pelajaran informatika yang lebih bersifat keilmuan. Hal ini didukung oleh Google, code.org, ACM juga ikut mendukung lahirnya K12 CS Curriculum Framework, yang notabene telah diimplementasikan menjadi standar kurikulum untuk sekolah dasar dan menengah di negara maju. Standar kurikulum K12 yang dirintis oleh ACM dan CSTA pun mengalamai penyesuaian dengan lahirnya kerangka kurikulum tersebut. CT menjadi salah satu aspek yang menjadi target kompetensi dalam kurikulum tersebut. K12 CS Curriculum telah diadaptasi oleh Indonesia untuk diimplementasikan sebagai kurikulum nasional pendidikan dasar dan menengah, yang telah disahkan pada tanggal 20 Desember 2018 sebagai Permen 36 dan Permen 37 Tahun 2018. Selama ini guru-guru yang mengajar TIK berfokus pada penggunaan tools, sehingga perlu ditansformasi menjadi guru yang mampu mengajar aspek keilmuan informatika, termasuk CT. Hubungan perguruan tinggi bidang computing dengan sekolah, saat ini masih minim. Seharusnya bila lulusan SMA sudah menguasai CT dan dasar informatika, pembelajaran di perguruan tinggi dapat lebih baik mutunya, karena materi dasar dan kemampuan CT sudah dikuasai oleh calon mahasiswanya. Di negara maju, sebagian besar mata kuliah tahun pertama, bahkan tahun kedua sudah diajarkan di jenjang SMA, sehingga topik masa kini seperti AI (Artificial Intelligence), Claud Computing, Big Data, dan Internet of Thing (IoT) dapat mulai diajarkan dengan lebih mendalam di jenjang perguruan tinggi. Sedangkan di Indonesia materi TIK untuk siswa SMA belum sampai pada topik masa kini seperti di negara maju. Sebagian besar perguruan tinggi yang ada di Indonesia telah mengacu kurikulum international, salah satunya adalah ACM. Sebagaimana diketahui ACM adalah salah satu yang mendukung berdirinya K-12, yaitu curriculum framework sekolah-sekolah di negara maju. Maka sebagaian besar mahasiswa yang ada di Indonesia sudah diberikan mata kuliah untuk substansi negara maju. Sayangnya sejak tahun 2013 mata pelajaran di Indonesia sudah menghilangkan mata pelajaran TIK, dan bila ditinjau lebih jauh bahwa mata pelajaran TIK yang ada di Indonesia pun masih jauh dari ranah informatika, karena materi yang diajarkan pada pelajaran TIK pada saat itu adalah sebagaian besar mengajarkan tentang aplikasi microsoft office seperti, ms word, excell, power point, dan sedikit apllikasi tambahan, sedikit sekali diberikan logika pemrograman, atau topik-topik untuk memecahkan persoalan informatika. Salah satu cara 
mengevaluasi keberhasilan sistem pendidikan di tingkat dasar sampai menengah adalah dengan memanfaatkan hasil test PISA (Programme for International Student Assessent), yaitu survei yang dilakukan oleh Organisasi for Economic Co-operation and Development (OECD) yang bertujuan untuk mengevaluasi sistem pendidikan di berbagai negara dengan menguji kemampuan dan pengetahuan siswa berumur 15 tahun dalam bidang sains, kemampuan membaca, dan matematika[2]. Dari hasil test PISA yang dilakukan pada tahun 2015 [3], bahwa nilai siswa Indonesia masih di bawah rata-rata. Indonesia berada pada urutan 62 dari 70 peserta, jauh berada di bawah Singapore (urutan 1) dan Thailand pada urutan 54. Menurut laporan PISA, Indonesia mengalami peningkatan yang kuat dalam bidang matematika dan membaca. Dilaporkan juga bahwa siswa di Indonesia kelas sekolah menengah (kelas 10 atau lebih) memiliki kinerja yang lebih baik dalam sains. Hal ini dikarenakan jam pelajaran sains diadakan setiap satu minggu dan lebih dari $96 \%$ siswa hadir di kelas saat pelajaran. Walau demikian, peringkat Indonesia masih di bawah rata-rata, dan bahkan jauh tertinggal bila dibandingkan dengan negara dekatnya yaitu Singapore yang berada pada urutan 1. Untuk itu perlu adanya dukungan dari pemerintah maupun pihak akdemik untuk mendorong siswa-siswa sekolah dasar, sekolah menengah, dan sekolah menengah atas agar mampu bersaing di bidang sains dan informatika secara menerus dan berkelanjutan agar tidak tertinggal dari negara lainnya.

Tabel Hasil Test PISA Siswa Indonesia Tahun 2015

\begin{tabular}{|l|c|c|}
\hline \multicolumn{1}{|c|}{ Bidang } & $\begin{array}{c}\text { Nilai Rata-rata } \\
\text { Test PISA }\end{array}$ & $\begin{array}{c}\text { Nilai yang dicapai } \\
\text { siswa Indonesia }\end{array}$ \\
\hline Sains & 493 & 403 \\
\hline Membaca & 493 & 397 \\
\hline Matematika & 490 & 386 \\
\hline
\end{tabular}

\section{METODE PELAKSANAAN}

Konsep pembelajaran pada usia dini sangat penting untuk pemahaman yang lebih tentang berbagai topik informatika. Fokus pembelajaran konsep informatika dalam pengembangan pemikiran komputasi yaitu lebih dikenal dengan Computational Thinking terdiri atas [4] :

1. Merumuskan masalah dengan cara yang memungkinkan siswa untuk menggunakan komputer dan alat lain dalam menyelesaikannya tugas/ soal.

2. Mengelola dan menganalisis data secara logis.

3. Mewakili data melalui abstraksi seperti model dan simulasi.

4. Otomatisasi solusi melalui pemikiran algoritmik

5. Identifikasi, analisis, dan implementasi solusi yang mungkin untuk solusi yang paling efisien dan efektif.

6. Generalisasi dan transfer proses penyelesaian masalah.

Hal ini bisa dilihat pada soal-soal yang diberikan, sebagai contoh untuk soal tingkat sekolah dasar[5] :

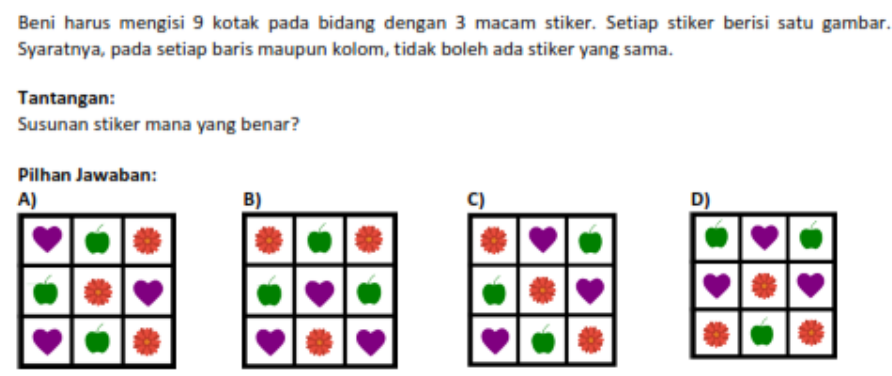


Jawaban yang tepat adalah $\mathrm{C}$ :

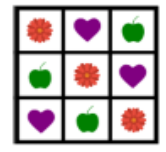

Kotak A salah, sebab ada sedikitnya 1 kolom dengan dua stiker yang sama.

Kotak B salah, sebab ada sedikitnya 1 baris dengan dua stiker yang sama.

Kotal D salah, sebab ada sedikitnya 1 baris dengan dua stiker yang sama.

Persoalan di atas adalah masalah sehari-hari yang diselesaikan dengan informatika, yaitu pertama dengan mencermati semua baris dan kolom. Bisa dilakukan dengan mencermati semua baris dulu atau kolom terlebih dahulu. Kedua, bila sudah menemukan salah satu baris atau kolom yang salah maka berikutnya adalah mengamati baris atau kolom lainnya. Hal ini disebut dengan eliminasi dalam ilmu informatika.

Dalam kehidupan sehari-hari, eliminasi membantu dalam proses menyelesaikan persoalan. Misalnya, saat menjawab pertanyaan pilihan ganda, siswa dapat mengabaikan jawaban yang tidak tepat untuk memilih jawaban yang tepat. Hal ini harus dilakukan secara terus menerus untuk melatih keterampilan yang digunakan tidak hanya untuk memecahkan persoalan test tetapi juga dapat diimplementasikan dalam kehidupan sehari-hari. Untuk itu diperlukan tahapan, yaitu sebagai berikut :

Adapun tahapan yang dilakukan dalam memecahkan persoalan di atas adalah dengan melalui tahapan sebagai berikut:

1. Mengikuti workshop computational thinking

2. Memberikan sosialisasi CT kepada dinas pendidikan, guru dan siswa sekolah dasar, menengah, dan atas.

3. Memberikan pelatihan-pelatihan/ workshop tentang CT

4. Mengikuti lomba/ tantangan Bebras yang diadakan setiap tahun sekali di Indonesia.

\section{HASIL DAN PEMBAHASAN}

\subsection{Pendidikan Informatika pada Kurikulum K-12}

Pendidikan Ilmu Komputer (CS) di sekolah dasar atau menengah, juga menengah atas memasuki dekade kelima keberadaannya di dunia. Israel adalah salah satu negara pertama yang mulai menawarkan kursus CS di sekolah menengah pada pertengahan tahun 1970-an. Banyak negara-negara Eropa melompat ke proses ini satu dekade kemudian. Agar siap untuk pekerjaan abad ke-21, siswa tidak hanya harus melek secara digital tetapi juga memahami konsep-konsep kunci dari CS. Siswa perlu memahami bahwa CS menggabungkan prinsip-prinsip teoretis dan keterampilan aplikasi. Mereka perlu memiliki kemampuan berpikir algoritmik dan memecahkan masalah dalam bidang akademik maupun bidang lain dalam kehidupan mereka.

Di Indonesia, CS dinamai oleh Informatika (informatika). Di awal mulanya, mengajar Informatika dimulai dengan pengajaran pemrograman. Pemrograman adalah cara yang baik untuk transfer penyelesaian masalah. Juga, pemrograman adalah cara terbaik untuk membangun bahasa untuk menginstruksikan (berkomunikasi dengan) mesin. Informatika sedang mengembangkan konsep dasar komunikasi, pengetahuan, data, interaksi dan informasi, dan menghubungkannya dengan fenomena seperti komputasi, bahasa, dan implementasi. Informatika mempelajari representasi, proses, dan komunikasi informasi dalam sistem alami dan rekayasa. Ini memiliki aspek komputasi, kognitif dan sosial. 
Informatika sebagai mata pelajaran terpisah di sekolah komprehensif adalah mengajar di sebagian besar negara-negara Eropa Timur, di mana tren pengajaran dan akademis lebih lazim sampai sekarang. Di Eropa, informatika diperkenalkan pada tahun 1986 di semua jenis sekolah menengah atas (kelas 11 dan 12). Sebagai subjek wajib atau sebagian wajib telah diterapkan di beberapa negara EropaTimur. Pengajaran tentang komputer dan pelatihan keterampilan pemrograman diubah dengan penggunaan praktis teknologi informasi dan komunikasi (TIK) untuk kegiatan sehari-hari.

Pendapat umum adalah bahwa dasar-dasar algoritma dan pemrograman adalah konsep kunci di sekolah pendidikan Informatika. Terutama belajar pemrograman dan pengkodean menjadi semakin populer di kalangan siswa dengan fokus pada desain web dan membuat aplikasi (aplikasi) untuk perangkat seluler. Lalu, konsep apa yang harus kita sertakan dalam pendidikan informatika selain dari algoritma dan pemrograman? Bagaimana kita dapat menggunakan teknologi informasi untuk pembelajaran kolaboratif untuk mewakili konsep-konsep ini untuk siswa dan memastikan pembelajaran yang produktif dan berkelanjutan? Sejak 2005, perhatian utama di sekolah-sekolah Indonesia diberikan untuk memenuhi kebutuhan pengguna dan untuk mengembangkan kemampuan komputer. Kurikulum informatika / TI di sekolah menengah pertama dan atas di Indonesia, skema evaluasi, dan bahkan denominasi telah diubah; namun demikian tetap menjadi subjek yang terpisah (teknologi informasi atau TI saat ini). Selain itu, salah satu komponen terpenting TI adalah membuat siswa sekolah komprehensif yang melek TIK.

Jika artikel ini berasal dari penelitian yang disponsori atau didanai oleh pihak tertentu, maka penulis dapat menuliskan penghargaan di bagian ini.

\subsection{Guru Teknologi Informasi/ Informatika K-12}

Guru adalah salah satu pemain kunci terpenting di dunia pendidikan. Sistem pendidikan, dan mereka menerapkan dan menyampaikan kurikulum di sekolah sehingga pendapat mereka tentang kurikulum Informatika sangat penting untuk perbaikan di masa depan. Guru juga perlu tahu bagaimana mengenali dan memecahkan masalah yang mungkin timbul di dalam kelas ketika mereka menyampaikan kurikulum.

Dagiene dalam penelitiannya [6] melakukan survey terhadap guru IT/ Informatika dan mendapat jawaban dari 337 guru IT / Informatika (sekitar 35 persen dari semua guru IT / Informatika). 90\% guru memiliki lebih dari 6 tahun praktik dalam mengajarkan disiplin ini, sementara sekitar 3 persen dari guru memiliki praktik kurang dari 3 tahun.

Para guru diminta untuk menyatakan bagaimana kurikulum TI / Informatika harus diperbaiki atau diubah. Seperti yang kita lihat, banyak guru menekankan pemrograman pengajaran pada tahap awal dan terus menerus. Guru memperhatikan bahwa banyak topik yang berhubungan dengan IT harus diajarkan pada usia yang lebih muda sehingga siswa dapat menggunakan keterampilan ini untuk pembelajaran yang lebih baik dari mata pelajaran lain. Tiga modul opsional (Pemrograman, Desktop publishing, dan pengembangan dan manajemen basis data) untuk tingkat menengah atas dibahas secara rinci dalam penelitiannya. Guru menyatakan sikap mereka tentang informatika sebagai mata pelajaran mendasar yang wajib bagi siswa dari segala usia: 161 guru sangat setuju dengan itu. Hampir semua guru IT / Informatika sepakat bahwa pengetahuan dasar informatika harus dikirimkan untuk setiap siswa di K-12 karena masyarakat membutuhkan lebih banyak pembuat teknologi, bukan hanya pengguna. Fisika misalnya menjelaskan hukum realitas, dan Informatika menjelaskan hukum realitas virtual. Siswa perlu berpikir secara algoritmik ketika menganalisis data dari kehidupan sehari-hari, siswa perlu berpikir secara komputasi ketika memecahkan masalah. Salah satu kegiatan yang dilakukan oleh 
Biro Bebras Udinus adalah melakukan sosialisasi kepada guru-guru IT yang ada di kota Semarang. Guru-guru sangat antusias dengan kegiatan yang sudah berjalan 2 tahun ini.

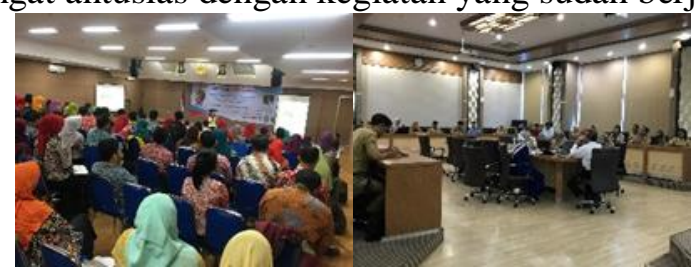

Gambar 1 Sosialisasi Computational Thinking pada Guru-guru TIK Kota Semarang, Tahun 2017-2018

\subsection{Kebangkitan Kurikulum Informatika}

Banyak negara, setidaknya di Eropa, sedang berupaya mengembangkan kurikulum Informatika (CS, Komputer, TI, dll.) Buku Putih oleh CSTA [21] mencantumkan sejumlah tantangan dan persyaratan yang harus dipenuhi jika ingin berhasil dalam meningkatkan pendidikan Informatika. Kurikulum Informatika / TI baru untuk sekolah-sekolah telah dirancang untuk memenuhi tantangan-tantangan berikut:

- Siswa harus memperoleh tinjauan luas tentang bidang Informasi (Ilmu Komputer);

- Instruksi harus fokus pada pemecahan masalah;

- Mengembangkan pemikiran algoritmik dan komputasi harus menjadi salah satu tujuan paling penting;

- Informatika harus diajarkan secara terpisah dari perangkat lunak aplikasi khusus, bahasa pemrograman, dan lingkungan;

- Informatika / TI harus diajarkan menggunakan masalah kondisi dunia nyata;

- Pendidikan informatika harus memberikan latar belakang yang kuat untuk penggunaan komputer secara profesional dalam disiplin ilmu lain

Kurikulum Informatika yang diperbarui terdiri dari beberapa bagian. Satu bagian sama untuk semua tingkat pendidikan K-12. Ini mencakup tujuan terpadu yang mendefinisikan lima bidang pengetahuan dalam bentuk persyaratan umum.

1) Informasi. Memahami dan menganalisis masalah - pemikiran logis dan abstrak; pemikiran algoritmik, algoritme, dan representasi informasi;

2) Teknologi digital. Menggunakan komputer, perangkat digital, dan jaringan komputer prinsip-prinsip fungsi komputer, perangkat digital, dan jaringan komputer; melakukan perhitungan dan menjalankan program;

3) Algoritma dan pemrograman. Pemrograman dan pemecahan masalah dengan menggunakan komputer dan perangkat digital lainnya - algoritma penandatanganan dan pemrograman; mengorganisir, mencari dan berbagi informasi; memanfaatkan aplikasi komputer;

4) Komunikasi virtual. Mengembangkan kompetensi sosial - komunikasi dan kerja sama, khususnya di lingkungan virtual; pembelajaran berbasis proyek; mengambil berbagai peran dalam proyek kelompok.

5) Keamanan, etika, prinsip-prinsip rendah. Memperhatikan prinsip dan peraturan hukum dan keamanan - menghormati privasi informasi pribadi, kekayaan intelektual, keamanan data, netiket, dan norma sosial; dampak positif dan negatif dari teknologi pada budaya, kehidupan sosial dan keamanan.

3.4 Dari Algoritma ke Computational Thinking ( Pemikiran Komputasi

Setengah abad yang lalu, kurikulum Informatika terutama berfokus pada algoritma dan pemrograman (atau pengkodean). Tidak semua siswa akan menjadi programmer profesional tetapi mereka menulis program sendiri, secara individu atau dalam kelompok, mereka mempraktikkan pemikiran kreatif dan komputasi, dan memperoleh keterampilan era digital 
yang berguna untuk kehidupan profesional dan pribadi. Siswa juga harus mendapatkan pengalaman dalam pemrograman berbagai instrumen digital, seperti mainan, robot, dan mesin penjual otomatis.

Pemecahan masalah dan CT (berpikir komputasi) adalah kemampuan penting yang harus diperoleh siswa sekolah dalam kegiatan sehari-hari mereka dengan menggunakan cara dan teknik yang berbeda. J. Wing telah membuat beberapa definisi[7]: Pemikiran komputasional melibatkan penyelesaian masalah, merancang sistem, dan memahami perilaku manusia, dengan menggambar konsep-konsep yang mendasar bagi ilmu komputer. Kemudian (pada 2011) topik direvisi dan CT didefinisikan sebagai proses pemikiran yang terlibat dalam merumuskan masalah dan solusi siswa. Dalam arti yang lebih luas, pemikiran komputasi mencakup banyak komponen pemecahan masalah, yaitu :

- Perumusan dan penyajian kembali tugas;

- Analisis data;

- Penguraian;

- Pemodelan dan simulasi;

- Otomasi keputusan;

- Penggunaan sumber daya secara efisien; dan

- Abstraksi proses pengambilan keputusan.

Keterampilan berpikir komputasi didukung dan ditingkatkan oleh sejumlah disposisi atau sikap yang merupakan dimensi penting dari Informatika dan literasi digital. Perbedaan utama antara menggunakan teknologi informasi dan berpikir secara komputasi adalah lebih dari sekadar menggunakan alat teknologi informasi dan informasi untuk menciptakan alat dan informasi.

\subsection{Bebras Challenge (Tantangan Bebras), sebuah cara untuk memperkenalkan konsep Informatika dan Pemikiran Komputasi}

Pemikiran komputasi berkaitan erat dengan mempelajari konsep-konsep Informatika. Konsep informatika memainkan peran sentral untuk memahami dasar-dasar komputer, teknologi informasi, perangkat lunak, perangkat keras, dan perangkat lainnya. Namun, dalam praktiknya, sangat sering pelatihan dalam perangkat lunak aplikasi diberikan lebih banyak di sekolah dibandingkan untuk eksplore lebih dalam ke konsep-konsep Informatika[6].

Tantangan Bebras, untuk semua siswa sekolah dimulai pada tahun 2004 dan diorganisasikan di Lithuania. Tujuan utama dari tantangan Bebras adalah untuk mempromosikan minat siswa pada Informatika sejak awal sekolah dan mengarahkan mereka untuk mengembangkan kemampuan berpikir komputasi. Sebenarnya, idenya adalah untuk melibatkan siswa ke dalam kegiatan penyelesaian tugas Informatika dan untuk menggunakan pemikiran komputasi dan teknologi modern lebih intensif dan kreatif[8].

Tantangan Bebras berfokus pada lima kelompok umur (beberapa negara mencoba mempunyai tiga atau empat grup) dengan koleksi tugas yang berbeda untuk setiap grup. Peserta termuda adalah siswa sekolah dasar (8-9 tahun) dan peserta tertua adalah siswa sekolah menengah atas (17-19 tahun). Ini adalah tantangan pemecahan masalah Informatika dengan soal-soal yang membutuhkan pemecahan masalah dan pemikiran algoritmik yang merupakan bagian dari pengembangan pemikiran komputasi. Soal bebras biasanya singkat, dapat dijawab dalam beberapa menit melalui antarmuka yang terkomputerisasi, dan membutuhkan keterampilan berpikir mendalam di bidang Informatika. Soal harus dijawab tanpa pengetahuan informatika sebelumnya, dan soal jelas terkait dengan konsep-konsep informatika dasar. Untuk menyelesaikan soal-soal itu, siswa sekolah diharuskan untuk berpikir dalam dan tentang informasi, struktur diskrit, komputasi, pemrosesan data, visualisasi data, dan soal tersebut harus 
menggunakan konsep algoritmik serta pemrograman. Tugas Bebras dapat mendemonstrasikan aspek Informatika dan menguji kemampuan peserta dalam memahami dasar Informatika.

Siklus belajar konsep informatika (siklus spiral) dimulai dengan konsep Informatika tertentu, yang merupakan gagasan utama apa yang ingin diajarkan kepada siswa (Gbr. 3). Soal dibuat dengan menambahkan cerita yang lucu dan menarik. Dengan menggunakan penerapan prinsip permainan dalam konteks bukan permainan, dan dengan menambahkan komponen interaktif (menyeret, menjatuhkan, dll.) soal yang dibuat untuk tantangan Bebras. Langkah selanjutnya adalah siswa menyelesaikan soal, dengan memahami tugas daripada sekadar menebak. Guru dapat membantu siswa untuk memahami soal setelah selesai mengerjakan soal dengan menjelaskan mengapa informatika itu penting.

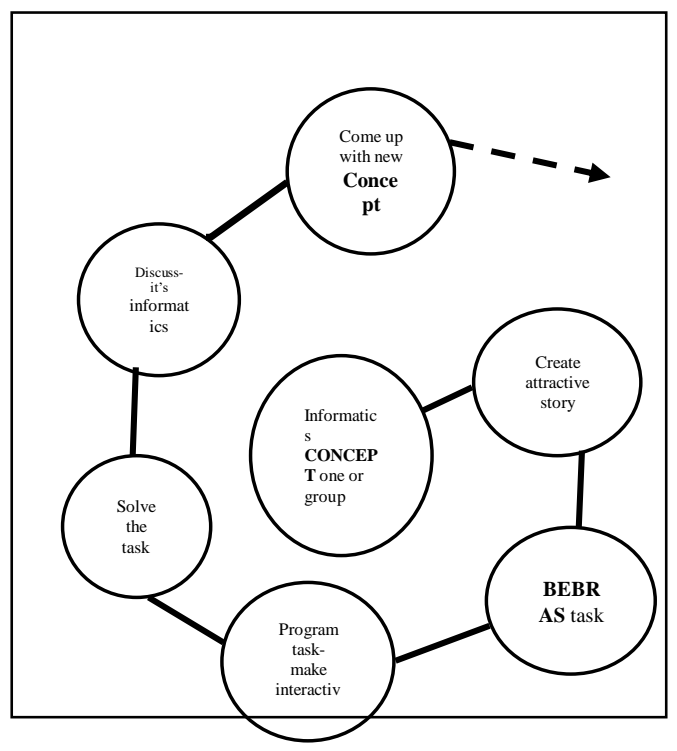

Gambar 2. Dari Konsep informatika hingga siswa memahami sudut pandang Guru

Universitas Dian Nuswantoro telah berpartisipasi dalam kegiatan Tantangan Bebras (Bebras Challenge) selama dua tahun terakhir ini. Kegiatan tersebut disambut sangat antusias oleh sekolah yang ada di kota Semarang. Tantangan ini merupakan hal yang baru dan menyenangkan bagi siswa sekolah dasar, menengah, maupun tingkat atas. Belajar tetapi seperti bermain.

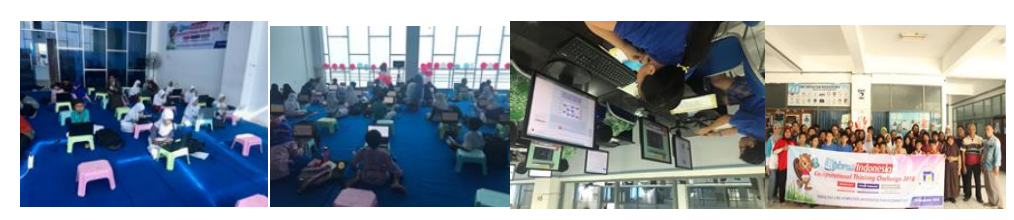

Gambar 3. Kegiatan Tantangan Bebras di Fakultas Ilmu Komputer Kampus Universitas Dian Nuswantoro, Tahun 2018

Jumlah partisipasi tantangan Bebras di Indonesia adalah 4677 peserta yang terdiri dari 1092 siswaSD, 1688 peserta siswa SMP, dan 1897 siswa SMA. Hasil yang diperoleh dengan kategori nilai > dari 70 untuk siswa SD 5\%, siswa SMP 6\%, dan SMA 1\%; nilai antara 50 sampai 70, untuk siswa SD 12\%, siswa SMP 15\%, dan siswa SMA 8\%; kategori nilai 0 sampai 50 untuk siswa SD 77\%, siswa SMP 67\%, dan siswa SMA 83\%; dan masih ada nilai di bawah 0, yaitu untuk siswa SD 6\%, siswa SMP 11\%, dan siswa SMA 7\%. Dari hasil terlihat pada tabel 2. bahwa nilai yang diperoleh siswa-siswa di Indonesia belum maksimal, masih dominan di kategori ke 2 yaitu $(0<$ nilai $\leq 50)$. Sama halnya dengan siswa di kota Semarang pada tabel 3 masih dominan di kategori ke 2. 
Tabel 2. Hasil Tantangan Bebras Indonesia Tahun 2018

\begin{tabular}{|l|r|r|r|r|c|c|r|r|}
\hline \multirow{2}{*}{ Kategori } & \multicolumn{2}{|c|}{ Nilai $\leq 0$} & \multicolumn{2}{|c|}{$0<$ Nilai $\leq 50$} & \multicolumn{2}{c|}{$50<$ nilai $\leq 70$} & \multicolumn{2}{|c|}{$70<$ nilai $\leq 100$} \\
\cline { 2 - 9 } & Jml & $\%$ & \multicolumn{1}{c|}{ Jml } & $\%$ & Jml & $\%$ & Jml & $\%$ \\
\hline SD & 64 & 6 & 836 & 77 & 134 & 12 & 58 & 5 \\
\hline SMP & 18 & 11 & 1134 & 67 & 260 & 15 & 105 & 6 \\
& 9 & & & & & & & \\
\hline SMA & 13 & 7 & 1583 & 83 & 150 & 8 & 28 & 1 \\
& 6 & & & & & & & \\
\hline
\end{tabular}

Tabel 3. Hasil Tantangan Bebras di Kota Semarang, tahun 2018

\begin{tabular}{|l|c|c|c|c|c|c|c|c|}
\hline \multirow{2}{*}{ Kategori } & \multicolumn{2}{|c|}{ Nilai $\leq 0$} & \multicolumn{2}{c|}{$0<$ Nilai $\leq 50$} & \multicolumn{2}{c|}{$50<$ nilai $\leq 70$} & \multicolumn{2}{c|}{$70<$ nilai $\leq 100$} \\
\cline { 2 - 9 } & Jml & $\%$ & Jml & $\%$ & Jml & $\%$ & Jml & $\%$ \\
\hline SD & 6 & 4 & 132 & 85 & 14 & 9 & 4 & 3 \\
\hline SMP & 4 & 5 & 63 & 72 & 19 & 22 & 1 & 1 \\
\hline SMA & 2 & 3 & 66 & 88 & 6 & 8 & 1 & 1 \\
\hline
\end{tabular}
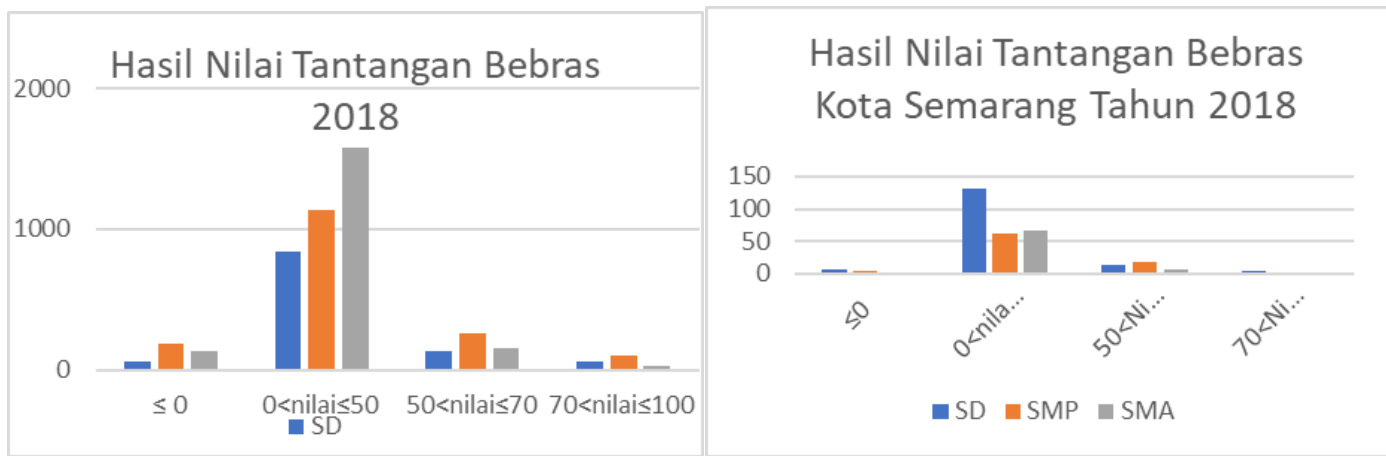

Gambar 4. Nilai Tantangan Bebras di Indonesia dan di kota Semarang, tahun 2018

\section{KESIMPULAN}

Pendidikan informatika telah muncul baru-baru ini di banyak negara. Generasi muda berusaha untuk menjadi pencipta dan pengembang teknologi baru. Banyak negara mulai membangun pendidikan Informasi di sekolah menengah pertama dan atas dan bahkan di sekolah dasar atau taman kanak-kanak. Beberapa negara telah merevisi atau menghidupkan kembali TI atau disiplin ilmu terkait yang diajarkan sekolah mereka. Begitupun dengan negara Indonesia, walaupun pelajaran PTI sempat ditiadakan di sekolah, namun sejak 2018 sudah dimunculkan lagi. Walaupun bukan menjadi mata pelajaran wajib, tetapi setidaknya sudah ada kesadaran dari lembaga pendidikan untuk menghidupkan dan menggiatkan lagi mata pelajaran komputer yaitu informatika.

Untuk keberhasilan implementasi Informatika sebagai disiplin sekolah, tindakan berikut harus dipertimbangkan: 1) keseimbangan kurikulum Informatika sesuai dengan bagian teoretis dan praktis (konsep dan keterampilan); 2) stimulasi diskusi di antara berbagai kelompok kepentingan (guru, orang tua, siswa, politisi, pemangku kepentingan, dll) tentang topik dan pengajaran Informatika; 3) refleksi arah pendidikan ilmu komputer internasional dan mempertimbangkan kekhasan nasional; 4) kompetensi dan motivasi guru untuk terus belajar hal-hal baru; 5) hubungan yang erat antara pendidikan Informatika formal dan informal. Pendidikan informatika harus ditanggapi dengan serius dan digabungkan berbagai kekuatan. Untuk memperoleh pemahaman mendalam tentang konsep-konsep Informatika, pelajaran 
formal tidak cukup menarik untuk menjaga motivasi siswa. Siswa harus didorong untuk bermain dengan konsep-konsep Informatika ini dalam kehidupan sehari-hari mereka.

\section{UCAPAN TERIMA KASIH}

Kami dari tim pengabdian mengucapkan banyak terimakasih kepada LPPM Universitas Dian Nuswantoro yang telah mendanai kegiatan pengabdian kami yang bertema Computational Thinking ini, sehingga berjalan dengan baik dan lancar.

\section{DAFTAR PUSTAKA}

[1] I. T. Bebras, "Bebras Computational Thinking Challenge," 2019.

[2] M. Ayub, M. C. Wijanto, W. F. Senjaya, O. Karnalim, and T. Kandaga, "Edukasi Berpikir Komputasional melalui Pelatihan Guru dan Tantangan Bebras untuk Siswa di Bandung pada tahun 2016," no. October, 2017.

[3] I. Indonesia, U. Nation, S. D. Goals, S. Indonesia, and V. Nam, “C Oecd 2016,” pp. 1-8, 201.

[4]V. Dagiene and G. Stupuriene, "Bebras - A sustainable community building model for the concept based learning of informatics and computational thinking," Informatics Educ., vol. 15 , no. 3 , pp. $25-44,2016$

[5]C. Commons, A. C.-N. Derivatives, and C. C. By-nc-sa, Tantangan Bebras Indonesia 2017 Bahan Belajar Computational Thinking Tingkat SD. 2017.

[6] V. Dagiene and G. Stupuriene, "Informatics Concepts and Computational Thinking in K-12 Education: A Lithuanian Perspective,” J. Inf. Process., vol. 24, no. 4, pp. 732-739, 2016.

[7] J. M. Wing, ““Computational Thinking' Communication of the ACM,” vol. 49, no. 3, pp. 33-35, 2006.

[8]V. Dagiene and G. Futschek, "Bebras A Contest to Motivate Students to Study Computer Science and Develop Computational Thinking," pp. 139-141, 2013. 